\title{
The first ultra-high resolution Digital Terrain Model of the shallow-water sector around Lipari Island (Aeolian Islands, Italy)
}

\author{
Alessandro Bosman ${ }^{1}$, Daniele Casalbore ${ }^{1}$, Marco Anzidei ${ }^{2,}{ }^{\star}$, Filippo Muccini $^{2}$, \\ Cosmo Carmisciano ${ }^{2}$, Francesco Latino Chiocci $^{3}$ \\ ${ }^{1}$ Istituto di Geologia Ambientale e Geoingegneria, Consiglio Nazionale delle Ricerche, Rome, Italy \\ 2 Istituto Nazionale di Geofisica e Vulcanologia, Rome, Italy \\ ${ }^{3}$ Sapienza Università di Roma, Dipartimento di Scienze della Terra, Rome, Italy
}

\author{
Article history \\ Received February 3, 2015; accepted March 7, 2015. \\ Subject classification: \\ Lipari, Multibeam bathymetry, Seafloor geomorphology, Aeolian Islands, Geohazard.
}

\begin{abstract}
Very high resolution bathymetric map obtained through multibeam echosounders data are crucial to generate accurate Digital Terrain Models from which the morphological setting of active volcanic areas can be analyzed in detail. Here we show and discuss the main results from the first multibeam bathymetric survey performed in shallow-waters around the island of Lipari, the largest and the most densely populated of the Aeolian Islands (southern Italy). Data have been collected in the depth range of 0.1-150 $\mathrm{m}$ and complete the already existent high-resolution multibeam bathymetry realized between 100 and $1300 \mathrm{~m}$ water depth. The new ultrahigh resolution bathymetric maps at 0.1-0.5 m provide new insights on the shallow seafloor of Lipari, allowing to detail a large spectrum of volcanic, erosive-depositional and anthropic features. Moreover, the presented data allow outlining the recent morphological evolution of the shallow coastal sector of this active volcanic island, indicating the presence of potential geo-hazard factors in shallow waters.
\end{abstract}

\section{Introduction}

Since the beginning of 1930s, single-beam echosounders were used to produce early remote-sensing based bathymetric maps. In the last decades, seafloor mapping systems have undergone a technological revolution, especially through the development of multibeam echo-sounders (MBES). While the use of the former single beam sensors remains mainly restricted to recreational applications, multibeam systems allowed to extensively map continental margins, greatly enhancing the knowledge on geological and oceanographic processes that are sculpturing the seafloor [Augustin et al. 1994, Bourillet et al. 1996]. The main reason for such improvements in seafloor mapping is that MBES, with respect to single beam echo-sounders, are equipped with hundreds of narrow adjacent beams arranged in a fan-like swath of typically 90 to 170 degrees across, providing very high resolution measurements up to few centimeters. MBES mapping also benefited from GNSS satellite data to precisely positioning the vessel during surveys, also supported by on board integrated motion-sensors used to estimate and correct continuously the vessel motion (roll, pitch and yaw) during the survey. The GPS satellites of the Global Navigation Satellite System (GNSS) provides the precise position of the vessel and the MBES sensor during navigation even up to a few $\mathrm{cm}$ of accuracy, then collecting the soundings data in the WGS84 geodetic reference system. Additional sensors are used to determine the speed of sound in the water column along the routes, to correct for the refraction effect of the sound waves in response to changes in water density due to temperature, conductivity and pressure from shallow to deep waters. Finally, powerful computer systems equipped with advanced computer graphics support navigation data and the ongoing surveys in real time. The post-processing of large amount of MBES data (in the order of $10^{5}-10^{7}$ of soundings) has the final goal to produce Digital Terrain Models (DTM) of the investigated areas at very high resolution, giving unprecedented detailed 3-D views of the seafloor. Nowadays MBES technique represents the most significant advance in the field of seafloor and continental water basins mapping, becoming a crucial tool for marine geomorphological studies [Locat and Lee 2002, Morgan et al. 2003, Esposito et al. 2006 and references therein, Anzidei et al. 2008, Bosman et al. 2009, Blondel 2012, Romagnoli et al. 2012, Romagnoli et al. 2013a].

With the aim to produce a very high resolution 


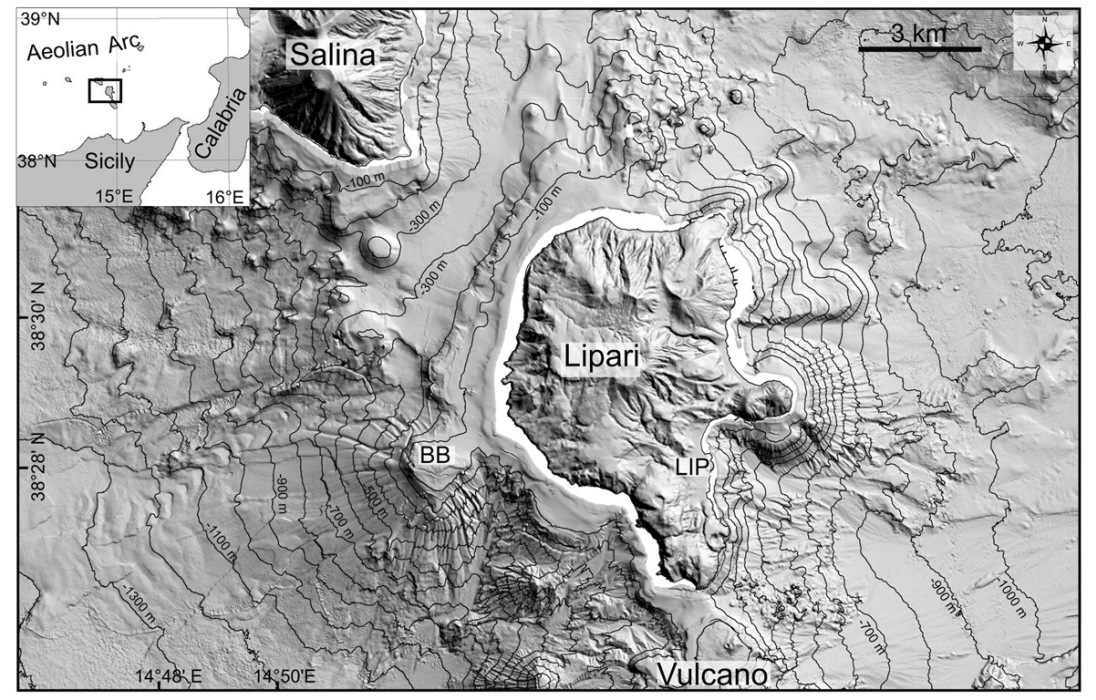

Figure 1. Shaded relief of Lipari edifice (modified from Casalbore et al. [2014c]). The white zone shows the area covered by the 2014 ultrahigh resolution multibeam surveys discussed in this paper, where shallow-water bathymetric data were lacking from previous surveys.

DTM of the shallow-water sector of the active volcanic island of Lipari (Aeolian Islands, Italy), an ultra-high resolution multibeam survey was carried out on September 2014. The aim of the paper is to present the technical details of the survey and briefly depict the first results arising from the ultra-high resolution multibeam bathymetry, evidencing possible implications on recent volcanism, tectonics and coastal hazard at Lipari Island.

\section{The investigated area:}

\section{tectonic and volcanic framework}

Lipari Island is the largest and the most densely populated among the Aeolian Islands (southern Tyrrhenian Sea; Figure 1 inset). It displays an area of about $38 \mathrm{~km}^{2}$ and represents the culmination of a broad largely submarine volcanic edifice (Figure 1) belonging to the Lipari-Vulcano-Salina volcanic belt [Casalbore et al. 2014c]. The eruptive history of Lipari spans between $\approx 267 \mathrm{ka}$ and medieval ages (AD 776-1220) and can be divided into nine epochs of activity interrupted by dormant periods, volcano-tectonic phases and episodes of terrace formation during the Last Interglacial [Calanchi et al. 2002, Forni et al. 2013]. Active tectonics along NNWSSE and subordinate N-S and E-W fault systems controlled several volcanic edifices that were active through time. Lipari, together with Vulcano and Salina Islands, is located at the northern end of a major NNW-SSE trending right-lateral strike-slip fault system, known as "Aeolian-Tindari-Letojanni". The latter has been interpreted as a tectonically active lithospheric discontinuity extending from the Aeolian Islands to the Ionian coast of Sicily [Serpelloni et al. 2011, Ventura 2013, Barreca et al. 2014]. It is worth noting that Lipari Island is only the tip of a large volcanic edifice that rises about $1300 \mathrm{~m}$ above the seafloor, reaching a peak of about
$602 \mathrm{~m}$ above sea level at Mt. Chirica. The submarine portion accounts for about the $80 \%$ of the entire areal of the edifice, so that several marine surveys were carried out in the last decade to map and characterize the main volcanic and erosive-depositional features offshore Lipari (Figure 1) [Romagnoli et al. 2013b, Casalbore et al. 2014a,b,c]. Nevertheless, the use of large Research Vessels (R/V Urania and Thetis belonging to the Consiglio Nazionale delle Ricerche) and the necessity of ensuring safety condition during the navigation, prevented from performing the surveying in shallow-water areas $(<-40 /-50 \mathrm{~m}$, white area in Figure 1), despite the areas close to the coastline represent the most critical for marine geohazards, especially in geologically-active setting [Chiocci et al. 2008, Casalbore et al. 2012, Bosman et al. 2014].

\section{The Multibeam bathymetric survey}

The multibeam bathymetric survey covered an area of $17 \mathrm{~km}^{2}$ and was performed at the end of September 2014. Data were collected all around the coast of Lipari Island mostly in the depth range between about 0.5 and $150 \mathrm{~m}$, using a $7 \mathrm{~m}$ long boat named BigOne belonging to the Istituto Nazionale di Geofisica e Vulcanologia (henceforth, INGV; Figure 2a). The vessel was equipped with a pole-mount at whose bottom end was installed a ultra-high resolution Teledyne RESON SeaBat 7125 SV2 multibeam system belonging to the Istituto di Geologia Ambientale e Geoingegneria of the National Research Council (Figure 2a). This system works at the frequency of $400 \mathrm{kHz}$ emitting up to 512 beams across a $140^{\circ} / 165^{\circ}$ wide swath; each beam has a width of $1^{\circ} \times 0.5^{\circ}$ (www.iho.int; International Hydrographic Organization [2005]). Besides the multibeam transducer, the system architecture (Figure $2 \mathrm{~b}$ ) 

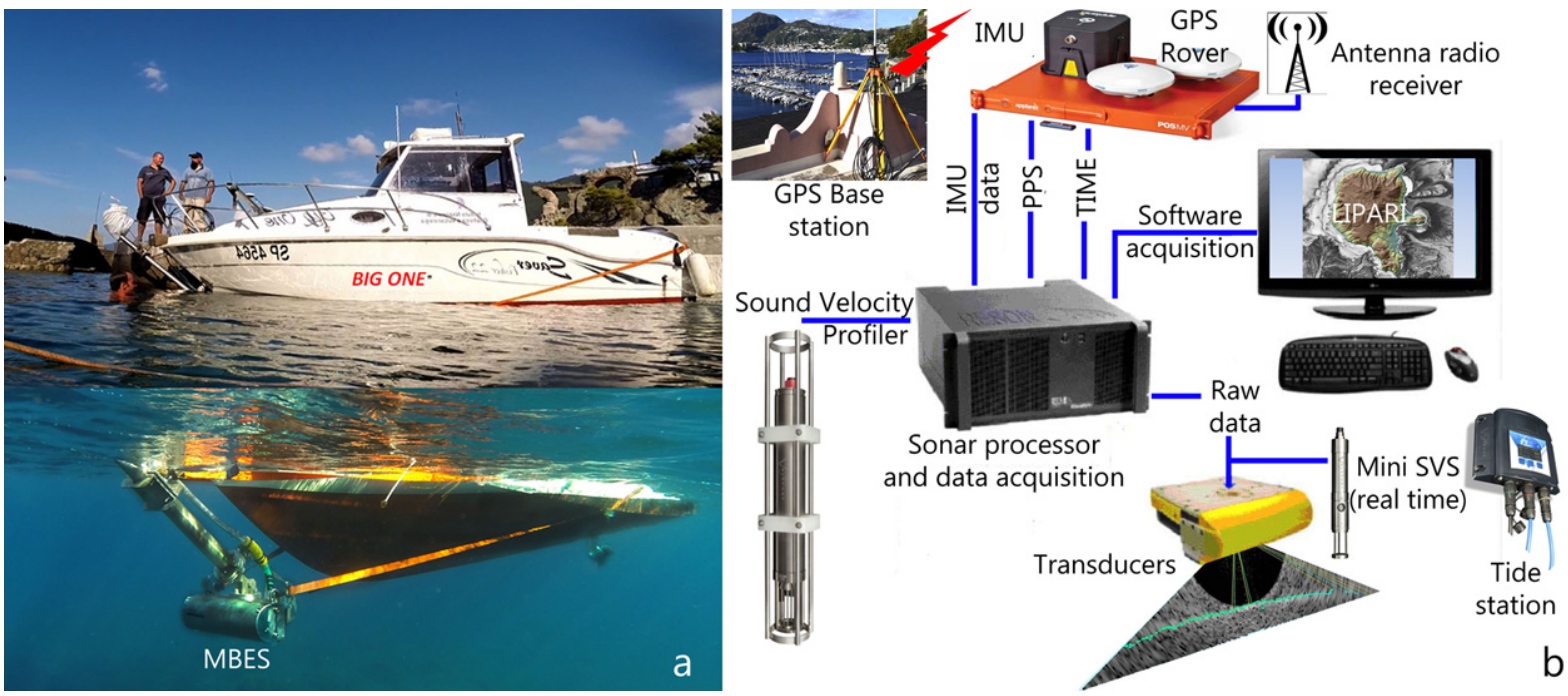

Figure 2. (a) The vessel "Big One" of the INGV equipped with the multibeam echo-sounder system; (b) multibeam system architecture of CNR-IGAG used during the ultra-high resolution bathymetric survey aroundLipari Island.

includes: i) a RTK-DGPS positioning system, ii) a sound velocity profiler, iii) a sound speed and temperature sensor used to update in real-time the sound velocity values close to the flat face of the multibeam transducer, iv) a portable tide gauge station, v) a main control center workstation to synchronize, process and store all the raw data files.

In detail, the vessel positioning was supplied in real-time by an Applanix Position and Attitude System (POS / MV 320 V5) using RTK corrections received by a temporary GPS master base-station located on land at Pignataro harbor, through a high frequency link at $1 \mathrm{~Hz}$ rate both in transmission and acquisition (blue triangle in Figure 3a). Raw GPS data were recorded both in the master base station at Pignataro (Trimble SPS receiver equipped with Zephir GPS antenna) and in the rover station (two Trimble antennas) mounted onboard the vessel for Post-Processing Kinematics (PPK) corrections. Horizontal and vertical positional accuracy of this system is typically of $+/-8 \mathrm{~mm}$ and $\pm 15 \mathrm{~cm}$, respectively. Attitude (pitch, roll, yaw, and heave) data were recorded at $100 \mathrm{~Hz}$ by the Inertial Motion Unit (IMU) with an average pitch, roll, and yaw with an accuracy of $\pm 0.03^{\circ}$, whereas heave accuracy was main-
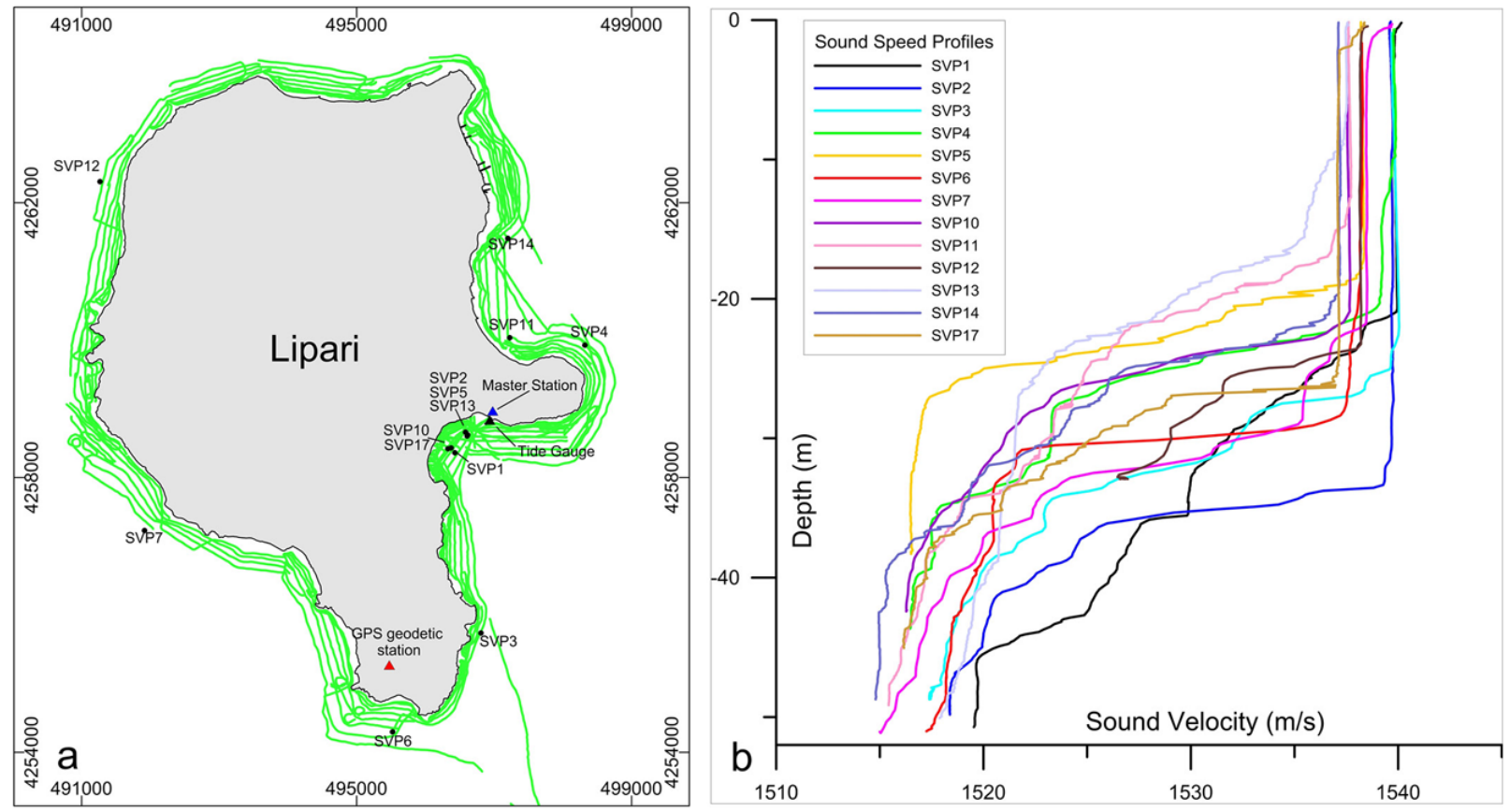

Figure 3. (a) Survey tracklines and positions of: i) tide gauge station (black triangle), ii) GPS master station (blu triangle), and iii) GPS geodetic station LOSV (red triangle). The latter was used as reference during post processing analysis. (b) Sound velocity profiles (black circles; see Figure 3a for locations) collected during the multibeam survey. 
tained at $\pm 5 \%$ or $5 \mathrm{~cm}$. Lever arm offsets of each instrument (multibeam transducer, GPS antennas) relative to the Inertial Measurement Unit (IMU) were measured at the beginning of the survey, as they serve to reference the multibeam data to true position and to properly apply motion compensation corrections. In order to minimize the offset estimation between the master GPS antenna, IMU sensor Reference Point and MBES, the devices were placed in an ad-hoc designed box and pole system.

Survey track lines (green lines in Figure 3a) were mostly run parallel to the isobaths and overlapping at $20 \%$ to guarantee the full coverage of the seafloor in the bathymetric range encompassed between the coastline (or at the minimum distance for safety of navigation) and the deeper multibeam dataset collected in the framework of the MaGIC Project (Figure 1; www.mag icproject.it). Patch tests (i.e. ad-hoc sounding lines acquired for the calibration of the multibeam sensor) in areas close to the survey zone were daily acquired on flat bottom and steep target between -10 and $-60 \mathrm{~m}$ : the tests were realized to compute roll, pitch, yaw angles and time delay of the MBES and IMU sensors.

Eighteen sound speed profiles were collected during surveys around Lipari Island using a Valeport SVP to correct for any variation in sound velocity due to temperature and salinity changes throughout the water column at $0.1 \mathrm{~m}$ depth intervals (Figures $3 \mathrm{a}$ and $3 \mathrm{~b}$ ). Moreover, real-time sound velocity close to the transducer was provided by a Valeport Mini-SVS mounted on its port side, since any error in this value would introduce an angular error both in the beam angle and the ray-tracing.

Tidal correction during surveys was performed using a portable tide gauge station (Tidemaster Valeport with accuracy $\pm 0.1 \%$ full scale) that was installed along the pier of Pignataro harbour (black triangle in
Figure $3 \mathrm{a}$ ) at $5 \mathrm{~m}$ water depth. Before the installation, the sensor has been calibrated on site based on the local oceanographic conditions. Tidal data were collected with a sampling rate of 4 minutes and thirty seconds of burst interval, successively compared and levelled to the averaged value recorded at the Ginostra tide gauge station of the Italian National Tidal Network (see www.mareografico.it for data and products), located in the nearby island of Stromboli (Figure 4).

\section{Data analysis}

\section{GPS data processing}

To define the geodetic reference frame of the collected data, we used data from the Global Positioning System (GPS) satellites analyzed in the Post-Processing Kinematic (PPK) mode. GPS data processing was performed in two steps: in the first we estimated the precise position of the temporary base station with respect to the GPS station LOSV (red triangle in Figure 3a) (LOSV position is: Lat $38^{\circ} 26^{\prime} 44.53^{\prime \prime}$; Lon $14^{\circ} 56^{\prime} 53.36^{\prime \prime}$; Height $273.30 \mathrm{~m}$ ). This station, which is the nearest to the investigated area, is belonging to the RING national GPS network managed by the INGV [Avallone et al. 2010]. In the second step, we estimated the RTK-DGPS kinematic positions of the rover GPS placed on board the vessel reprocessing the RTK solution using the corrections provided by LOSV station .

Data have been post-processed using POSPac MMS Software to reduce horizontal and vertical positioning uncertainties, based on the satellite constellation orbits, clock corrections, atmospheric delays coupled with attitude data $(\mathrm{L} 1+\mathrm{L} 2$, ephemeris precise). Postprocessed kinematic techniques were used to generate a Smoothed Best Estimate of Trajectory (SBET) file. SBET file is the output of a post-processing solution that tightly integrates the orientation and position data

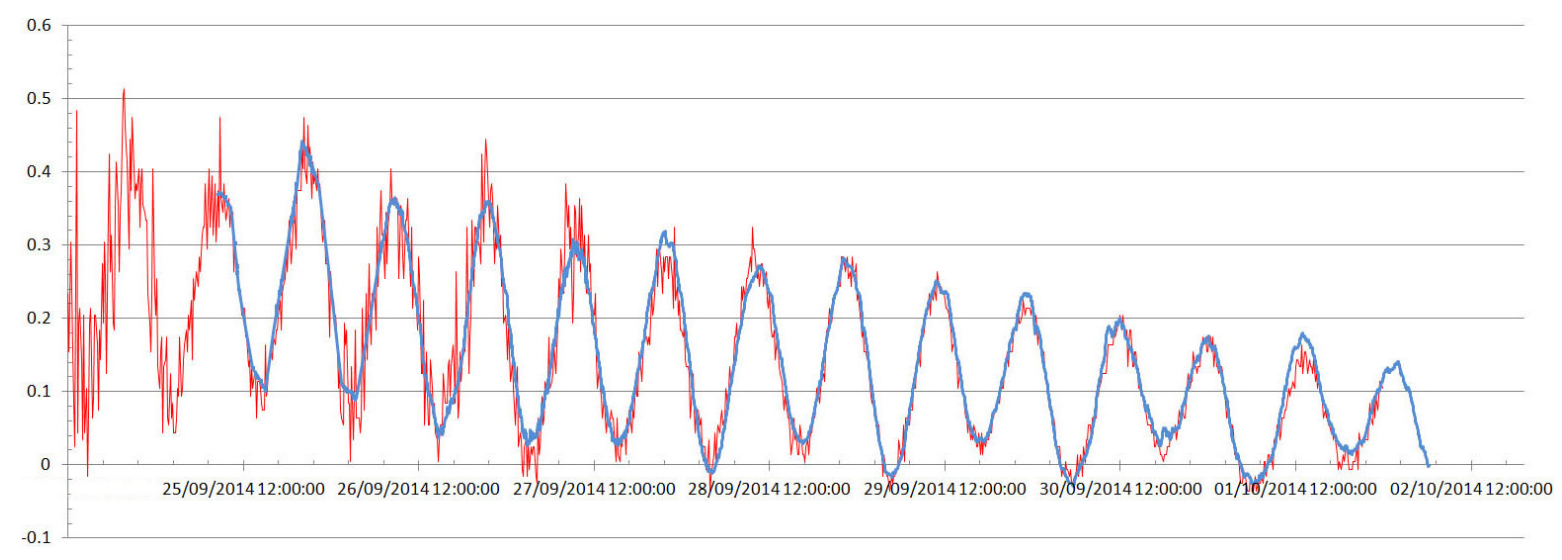

Figure 4. Leveling of tide gauge data collected by the local station installed during surveys at Pignataro harbor (in blue) with respect to averaged values from the Ginostra station (in red), located at Stromboli Island (data from the National Tide gauge Network, www.mareografico.it). Sampling rate is four minutes. 

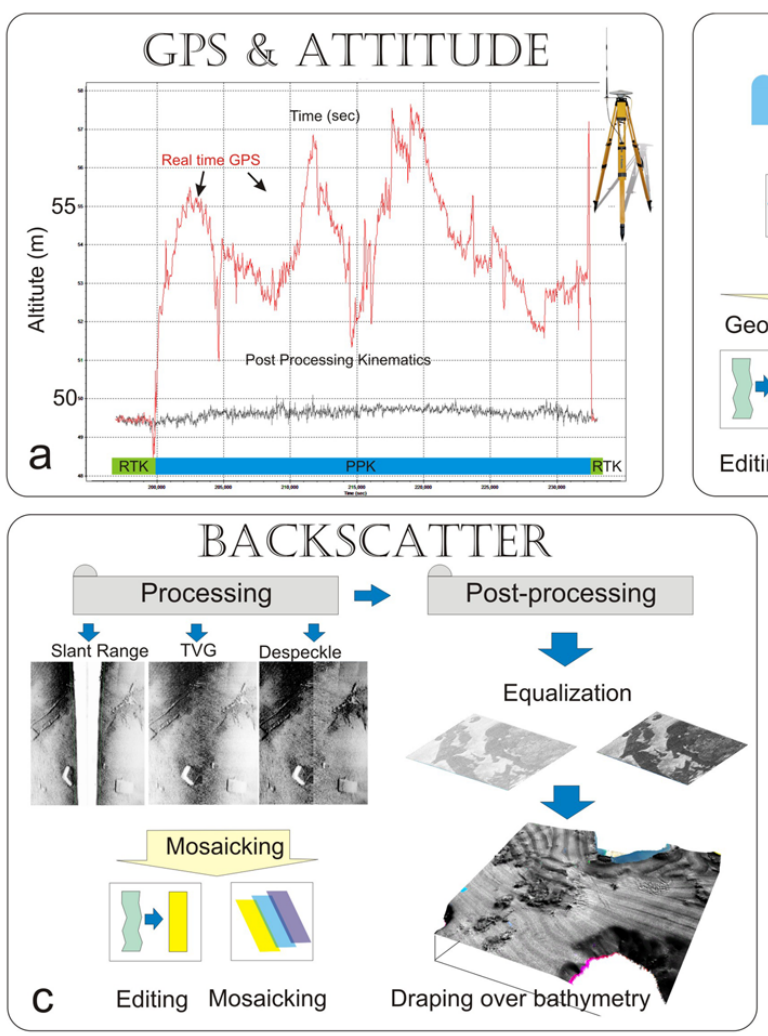
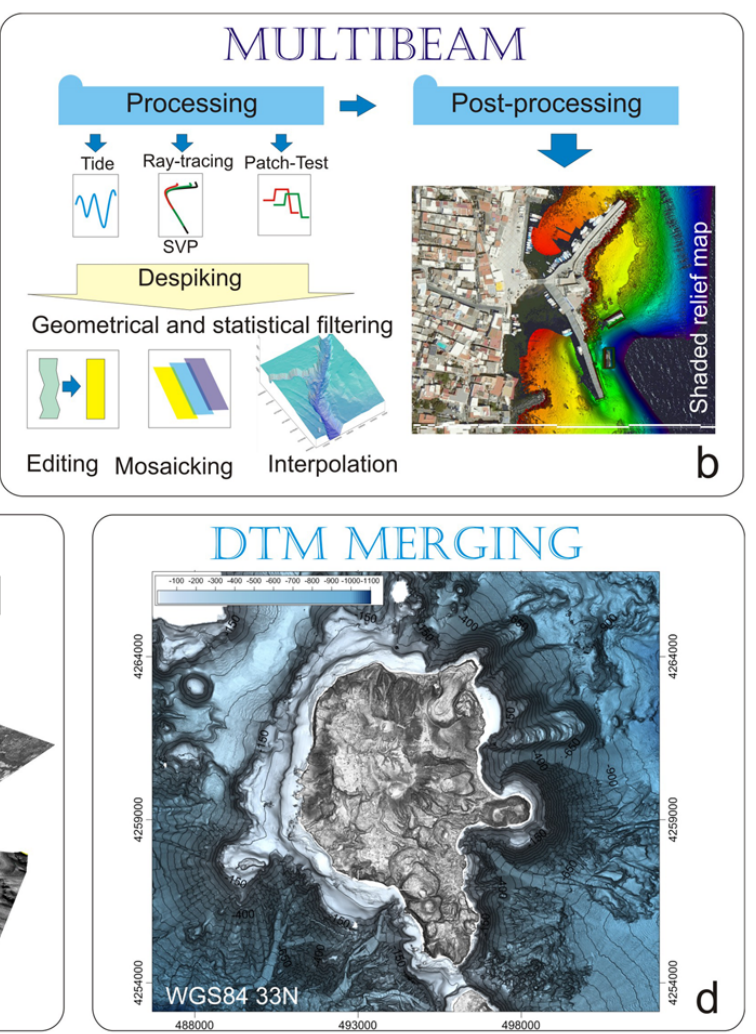

Figure 5. Flow chart of the multibeam data processing: (a) GPS and attitude; (b) bathymetric data; (c) backscatter data; (d) DTM merging. See text for details.

of the IMU and GPS sensors through statistical filtering. SBET solution includes rotational motion around the three axes, as well as heave due to surface waves and GPS tidal variation over the survey period, that were all tied to LOSV station. Finally, the 3D positions of the GPS rover placed on board of the vessel, have been estimated at a few centimeters level.

\section{Multibeam data processing and DTM generation}

Multibeam data processing was performed using Caris Hips and Sips 8.1 [CARIS 2000] encompassing the following steps (Figure 5): a) conversion and import of multibeam raw data files (s7k), b) application of tide data leveled to the Ginostra station, c) importing and replacing of the new Smoothed Best Estimated Trajectory on the raw multibeam data, d) ray-tracing by sound speed profiling with interpolation by time and/or distance between velocity depth-profiles, e) matching of multibeam lines by patch test on specific targets performed every day, f) application of statistical and geometrical (angle and distance) filters for each swath to remove coherent/incoherent noise, g) the manual deletion of spikes due to single fake soundings during editing. Some $600 \times 10^{6}$ processed soundings were merged and gridded (e.g. using a weighted averaging algorithm; Ware et al. [1991]) for the generation of DTMs at different resolutions: cell size, varying from $0.1 \mathrm{~m}$ in very shallow water (down to $-40 \mathrm{~m}$ ) to $0.5 \mathrm{~m}$ at greater depths. The final DTM in this work was realized with cell-size of $0.5 \mathrm{~m}$ (Figure 6). The sub-aerial DTM is ob-

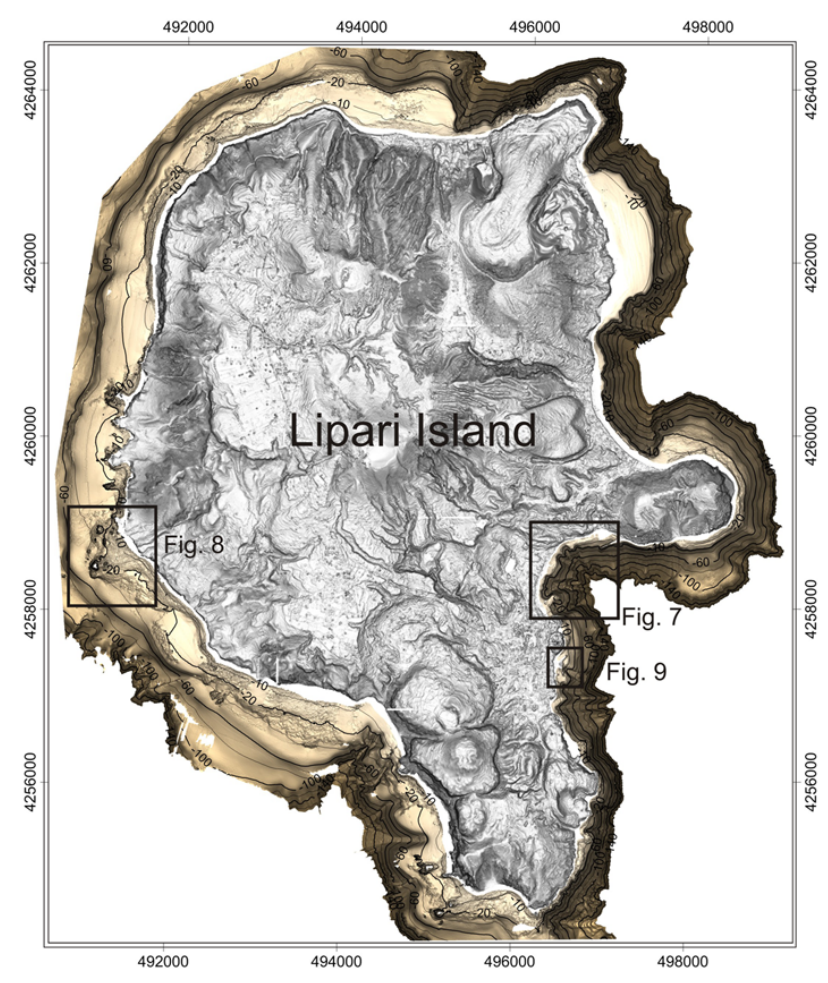

Figure 6. Shaded relief map of the ultra-high resolution multibeam bathymetry acquired during our surveys with the location of the areas (black squares) discussed in the text and in Figures 7, 8 and 9. Projection UTM 33N, Datum WGS84. 


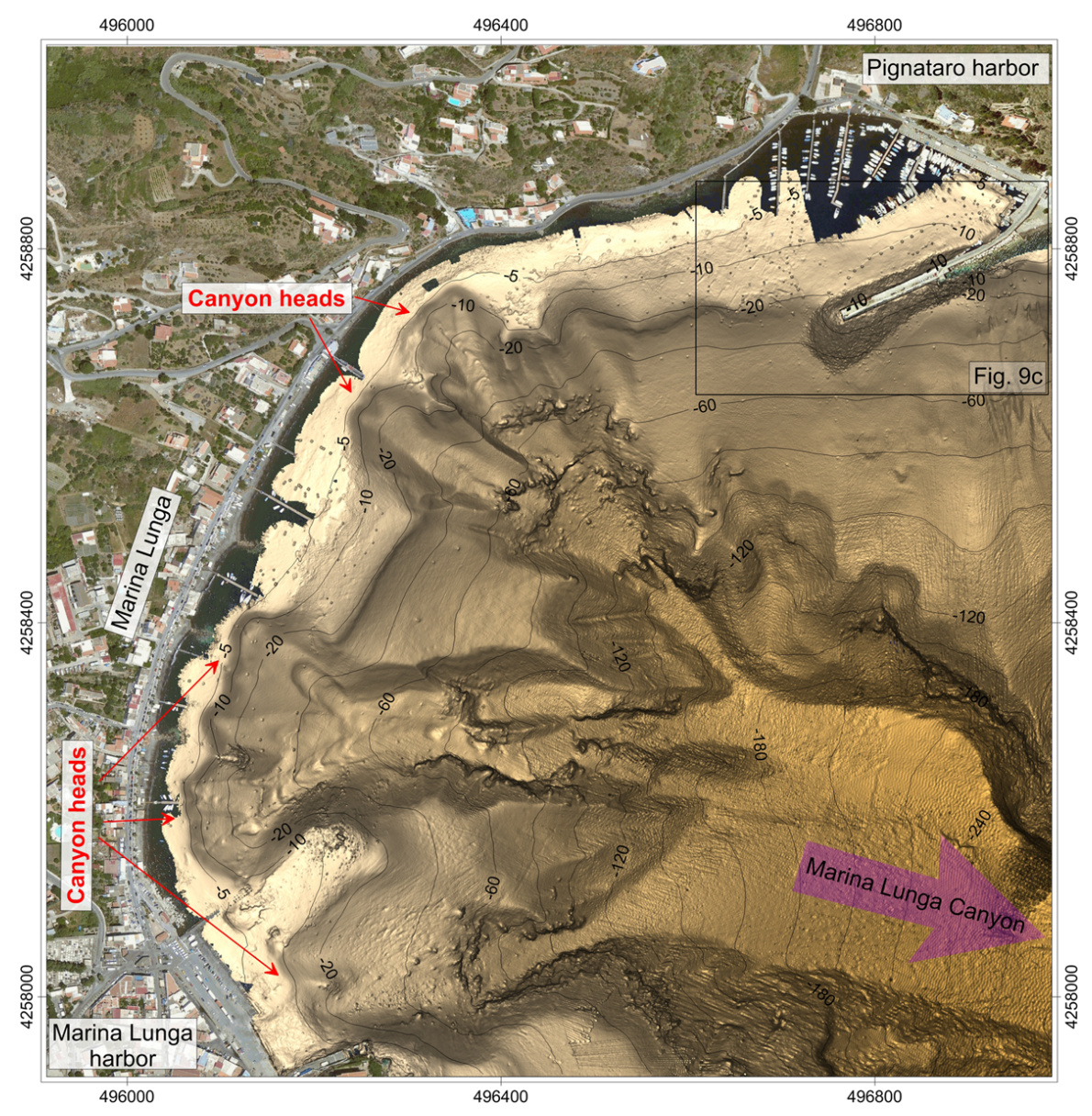

Figure 7. Shaded relief of the south-eastern part of Lipari Island. Note the several submarine canyons with retrogressive heads very close to the coastline. The upper-right box shows the location of the outer mole of Pignataro harbors

tained from LIDAR data, provided by the Ministero dell'Ambiente.

Moreover, the multibeam backscatter signal was processed through SIPS SST (Side Scan Tools), applying radiometric and geometric corrections to the data, including slant-range corrections based on the available bathymetry, as well as corrections for beam pattern effects and time and angle varying gain. SIPS SST also calculates the Time Variable Gain (TVG), despeckle and gain normalization (Figure 5). Multibeam backscatter mosaic was realized with a pixel size of $0.1 \mathrm{~m}$.

\section{The morpho-bathymetric map and preliminary analysis}

The preliminary analysis of the new morpho-bathymetric data reveals the presence of several unknown geomorphic features in the shallow-water sectors around Lipari Island. These are related to volcanic, erosive-depositional and biological processes as well as to the anthropogenic interference. The most remarkable features are a number of canyons, whose headwall extend up to $-5 \mathrm{~m}$ of depth and a few tens of meters far from the coasts (Figure 7). These features are mainly developed in the southern and eastern coast of the island, where the insular shelf is lacking (Figure 1; Romagnoli et al. [2013a], Casalbore et al. [2014c]). In contrast, the western part is mainly characterized by flat and relatively smooth seafloor surfaces, representing the top of four order of prograding depositional bodies interpreted as Submarine Depositional Terraces (SDT in Figure 8) by Chiocci and Romagnoli [2004]. SDT are characterized by a smooth seafloor, except for near-shore areas where blocky facies were often identified at $-20 \mathrm{~m}$ (Figure 8). The blocky facies represent the reworking of coarsegrained material derived from the erosion of submarine lava flows and rock-falls processes that affected the overlying coastal cliff. Sometimes, relict volcanic features crop out from the surrounding seafloor, rarely emerging from the sea as in the case of Pietra del Bagno islet (Figure 8). Large areas of SDT also show smallscale roughness of the seabed, due to the alternation of blocks with metric/sub-metric size, sandy areas and widespread Posidonia oceanica meadows down to $-40 \mathrm{~m}$, similarly to that observed at the nearby Stromboli Volcano. In detail, Posidonia meadows are easily recognizable on the data due to their peculiar morpho-acoustic facies and backscatter pattern (Figure 8). Anthropic features are observed off the main harbors, in the eastern part of the island. Particularly, several $2 \times 2 \mathrm{~m}$ of size mooring posts and two large tilted caissons facing the 
outer mole of Marina Piccola harbor (Figure 9).

Finally, it is remarkable the relief of an archaeological structure, likely a roman age pier located in the harbor of Lipari Marina Grande. This structure is about $150 \mathrm{~m}$ long and $20 \mathrm{~m}$ across and its top, largely buried by a thick layer of young sediments, is submerged up to a depth of about $-11 \mathrm{~m}$, inferring higher rates of land subsidence and relative sea level rise for this area with respect to other regions of the Mediterranean coasts [Pirazzoli et al. 1996, Morhange et al. 2001, Lambeck et al. 2004a,b, Lambeck and Purcell 2005, Anzidei et al. 2011, Anzidei et al. 2014b] and of the Aeolian Islands [Tallarico et al. 2003, Anzidei et al. 2014a]. This pier is currently under investigation by the archaeologists of the Soprintendenza del Mare della Sicilia that revealed part of the valuable constructional features of this site lying very close to the modern pier currently used by local navigation companies (http: / / www.regione.sici lia.it/beniculturali/archeologiasottomarina/).

The outer mole of Pignataro harbor is placed across the edge of the high-stand depositional terrace. Its end is laying on a steep slope at $25^{\circ}-29^{\circ}$ (Figures 7 and 9c). Widespread fractures observed along this structure can be related to seafloor instabilities that affected the foundations since the time of its construction.

\section{Discussion}

The new ultra-high resolution multibeam survey provided the first 3D detailed morpho-bathymetric map of the coastal seafloor of Lipari Island (i.e. between -0.1 and $-150 \mathrm{~m}$ ) at a resolution better than 0.5 $\mathrm{m}$ (Figure 6). Moreover, these data allowed to complete the previous seafloor mapping of the deeper submarine portion of Lipari edifice performed in the framework of the MAGIC project (http:/ / www.magicproject.it).

Although the volcanological and geomorphological interpretations are not the specific goals of this paper, which aims to present the bathymetric surveys and the first very high resolution map of the shallowwater sectors of Lipari Island, the collected data provide information on the geometry and characteristics of morphological features related to volcanic activity, sea-level changes, sliding or rock-fall processes as well as of submerged archaeological structures. The first new evidences arising from the very high resolution multibeam bathymetry can be summarized as follows:

- the set of four order of STDs lying between -10 and $-140 \mathrm{~m}$ characterizing the insular shelf of Lipari [Chiocci and Romagnoli 2004] appears well preserved along the western side of the island. Conversely, on the eastern side the terraces are absent or cut by submarine canyons that run up to the current shoreline;

- slide scars or rock-fall blocks are very common

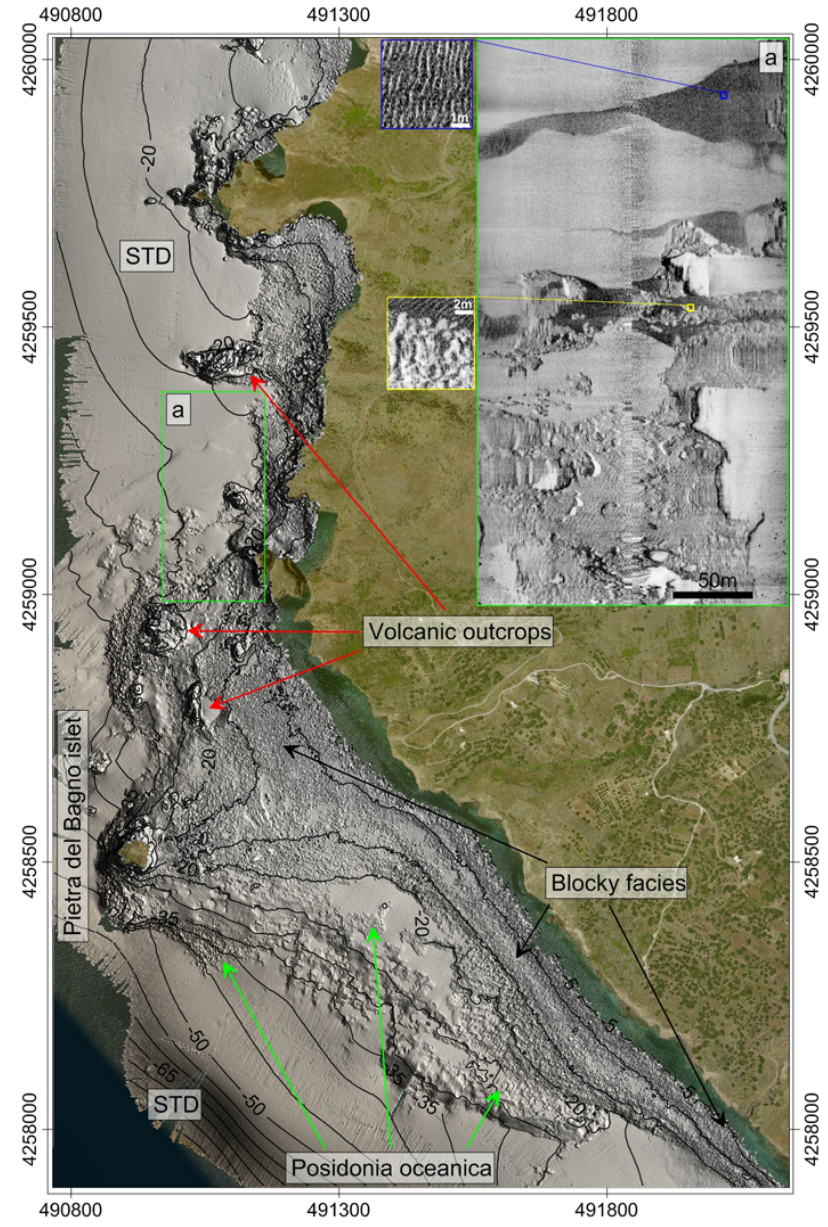

Figure 8. Shaded relief of the western sector of Lipari Island showing: i) volcanic outcrops, ii) blocky facies parallel to the coastlines, and iii) Posidonia oceanica meadows. In the inset an example of a multibeam backscatter image is shown (dark grey tones indicate high-backscatter areas). Upper and lower insets show enlarged details of sand ripples and Posidonia oceanica, respectively.

offshore the island, especially along the steepest coasts or at the outer edges of the submarine marine depositional terraces;

- despite the recent volcanic activity, data did not reveal any relevant submarine gas exhalative centers. This is in contrast with the nearby island of Panarea and Vulcano that show several active exhalative centers even with explosive features in the shallow seafloor [Esposito et al. 2006 and references therein, Monecke et al. 2012];

- in the area of Marina Grande, which is the location of the main commercial harbor of the island, the remnants and the shape of a long pier, probably of roman age, may correspond to the entrance of the ancient harbor of Lipari (http: / / www.regione.sicilia.it / beniculturali/archeologiasottomarina/);

- the occurrence of several active canyons heads very close to the coastline is relevant for hazard assessment of Lipari Island.

Therefore the new bathymetry opens questions on the recent geological evolution of this island suggesting further investigations through the integration of 


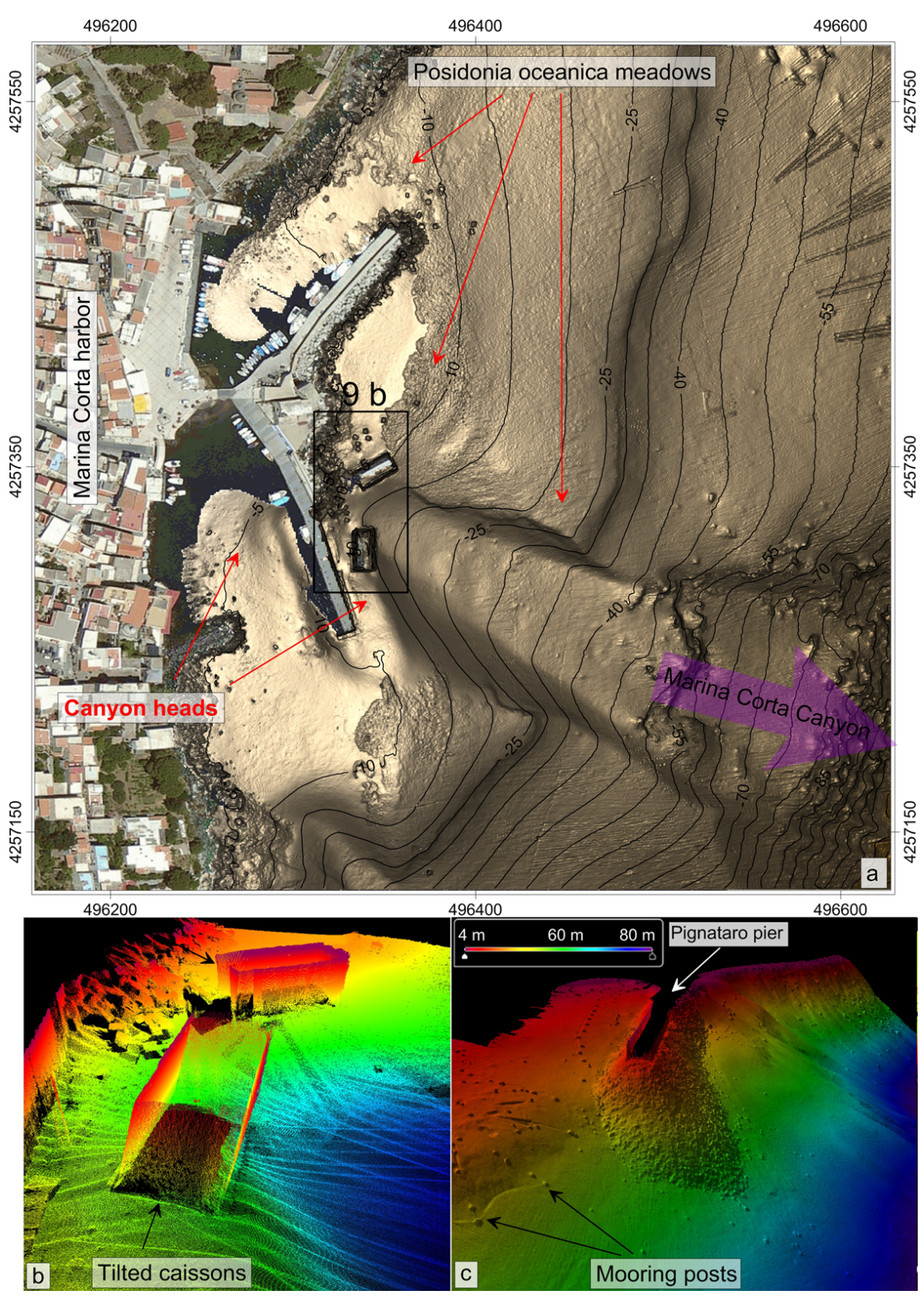

Figure 9. (a) Shaded relief of the coastal sector facing Marina Corta harbor (for location see the inset in Figure 6) showing the Marina Corta Canyon and anthropic structures; (b) 3-D views of the tilted caissons and mooring posts and the outer part of the mole at Pignataro harbor (for location see the inset in Figure 7).

different geological and geophysical studies. Mainly, if the subsiding behavior of Lipari inferred from instrumental geodetic [Mattia et al. 2008, Barreca et al. 2014] and historical data (Calanchi et al. [2002], Mazza [2013]; http://www.regione.sicilia.it/beniculturali/archeolo giasottomarina/) can be addressed to the interaction between tectonic structures, volcanic activity and retrogressive erosive processes mining the stability of the subaerial flanks. Moreover, the proximity of active canyon heads at the coast together with steep slope gradients may favor the onset of retrogressive submarine slides, as reported in other active canyons [Assier-Rzadkieaicz et al. 2000, Casalbore et al. 2012]. The latter may cause a loss of stability of the coastline and of the near offshore which can become the place of potential gener- ation for local tsunamis. In this regard, the bathymetric data can represent a reference base for future repeated bathymetric surveys in order to assess eventual changes in the morphology of the canyon heads related to slope failures. Although historical landslide-generated tsunamis are not reported at Lipari, tsunamigenic slides recently occurred at the head of active canyons close to the coastlines, such as for the Gioia Tauro Canyon in 1977 [Colantoni et al. 1992] and Var Canyon in 1979 [AssierRzadkieaicz et al. 2000], that caused heavy damage and some casualties along the nearby coasts. Cases of tsunamis triggered by coastal slides during moderate to large earthquakes or volcanic activity, are reported in the literature for the Italian coasts facing the Aeolian Islands, such as those occurred in 1783 at Scilla [Casalbore et al. 
2014d], in 1905 and 1908 near Pizzo Calabro and Messina [Mastronuzzi et al. 2013]. Similar events also occurred in the Aeolian Islands during the 2002-2003 eruption of Stromboli volcano [Maramai et al. 2005, Chiocci et al. 2008]. Regional tsunamis may also affect the coast of Lipari, such as in the case of the $2003, M=6.9$ Boumerdès earthquake in northern Algeria, that struck most of the coasts of the central Mediterranean, including Italy, causing damages and casualties [Vecchio et al. 2014, and references therein]. In this context, the presence of submarine canyons with high slopes near the coastline is a critical condition for the propagation of tsunami waves approaching the coast [Weiss 2008].

At Lipari, the steepest seafloor areas are close the town of Lipari with its industrial and touristic activities and coastal installations, therefore this area is particularly sensitive for potential geo-hazard. Further analysis of the morpho-bathymetric maps, in combination with additional marine (seismic, seafloor sampling, etc.) and aerial surveys are needed to better constraint the recent evolution of the island as well as to assess coastal dynamics and related hazard. In particular, the realization of a very high resolution terrestrial DTM, like for other active Italian volcanoes [Achilli et al. 1998, Baldi et al. 2006, Baiocchi et al. 2007, Pesci et al. 2007] and its integration with the present multibeam bathymetry will represent a further step for a comprehensive analysis of coastal hazards, including tsunami modeling for near and far-field sources and coastal slides, similarly to that was realized for the nearby Panarea Island [Fabris et al. 2010] or in continental volcanoes [Baiocchi et al. 2007].

\section{Conclusion}

The ultra-high resolution multibeam swath-bathymetry at 0.1-0.5 m performed in the shallow waters surrounding the coast of Lipari Island, allowed to complete the already existent DTMs for this area. Data revealed the presence of morphological structures which represent a potential marine geohazard for this active volcanic island. Particularly, the possible interaction between tectonic structures, volcanic activity and retrogressive erosive processes can threaten the stability of the submarine flanks of the Lipari edifice, with consequent natural hazards. Therefore, due to the presence of industrial installations and touristic activities, this area deserves the same monitoring and hazard assessment effort of any active volcano-tectonic region within an urbanized area.

Acknowledgements. This study has been funded by DPCINGV Project V3 (Multi-disciplinary analysis of the relationships between tectonic structures and volcanic activity), Regione Liguria (Scancoast), the Italian Ministry of Education, University and Research within the National Research Program 2011-2013 PRIN (Re sponse of morphoclimatic system dynamics to global changes and related geomorphologic hazard), Ritmare project for the implementation of the multibeam equipment and the Ministero dell'Ambiente e della Tutela del Territorio e del Mare-Geoportale Nazionale with license Creative Commons 3.0 Italy (CC BY-SA-3.0IT) for providing the terrestrial LIDAR data. We gratefully acknowledge the DPC Project coordinators Raffaele Azzaro and Rosanna De Rosa and Guido Ventura for insightful discussion, Riccardo Vagni, Captain of INGV vessel and Tenente di Vascello Paolo Margadonna of the Capitaneria di Porto at Lipari and Commander Marco Miuccio of the Capitaneria di Porto at Salina, for their valuable support during surveys.

\section{References}

Achilli, V., P. Baldi, L. Baratin, C. Bonini, E. Ercolani, S. Gandolfi, M. Anzidei and F. Riguzzi (1998). Digital photogrammetric survey on the island of Vulcano, Acta Vulcanologica, 10, 1-6.

Anzidei, M., M.L. Carapezza, A. Esposito, G. Giordano, M. Lelli and L. Tarchini (2008). The Albano Maar Lake high resolution bathymetry and dissolved $\mathrm{CO}_{2}$ budget (Colli Albani volcano, Italy): Constrains to hazard evaluation, Journal of Volcanology and Geothermal Research, 171, 258-268; doi:10.1016/j.jvolgeores.2007.11.024.

Anzidei, M., F. Antonioli, K. Lambeck, A. Benini and M. Soussi (2011). New insights on the relative sea level change during Holocene along the coasts of Tunisia and western Libya from archaeological and geomorphological markers, Quaternary International, 232, 5-12.

Anzidei, M., M. Esposito and M. Benini (2014a). Evidence of active subsidence at Basiluzzo Island (Aeolian Islands, southern Italy) inferred from a Roman age wharf, Quaternary International, 288, 158-167; doi:10.1016/j.quaint.2012.01.019.

Anzidei, M., K. Lambeck, F. Antonioli, S. Furlani, G. Mastronuzzi, E. Serpelloni and G. Vannucci (2014b). Coastal structure, sea-level changes and vertical motion of the land in the Mediterranean, Geological Society, London, Special Publications, 388 (1), 453-479.

Assier-Rzadkieaicz, S., P. Heinrich, P.C. Sabatier, B. Savoye and J.F. Bourillet (2000). Numerical modelling of a landslide-generated tsunami: the 1979 Nice event, Pure and Applied Geophysics, 157 (10), 1707-1727.

Augustin, J.M., C. Edy, B. Savoye and E. Le Drezen (1994). Sonar mosaic computation from multibeam echosounder, Oceans'94, 2, 433-438.

Avallone, A., G. Selvaggi, E. D’Anastasio, N. D’Agostino, G. Pietrantonio, F. Riguzzi, E. Serpelloni, M. Anzidei, G. Casula, G. Cecere, C. D’Ambro-sio, P. De Martino, R. Devoti, L. Falco, M. Mattia, M. Rossi, F. Obrizzo, U. Tammaro and L. Zarrilli (2010). The RING network: improvement of a GPS velocity field in the central Mediterranean, Annals of Geophysics, 53 (2), 39-54. 
Baiocchi, V., M. Anzidei, A. Esposito, U. Fabiani, G. Pietrantonio and F. Riguzzi (2007). Integér bathymétrie et lidar, Géomatique, 55, 32-35.

Baldi, P., M. Fabris, M. Marsella, R. Monticelli and V. Achilli (2006). Application of Digital Terrain Model to volcanology, Annals of Geophysics, 49 (4/5), 1059-1066.

Barreca, G., V. Bruno, F. Cultrera, M. Mattia, C. Monaco and L. Scarfi (2014). New insights in the geodynamics of the Lipari-Vulcano area (Aeolian Archipelago, southern Italy) from geological, geodeticand seismological data, Journal of Geodynamics, 82, 150167; http: / / dx.doi.org/10.1016/j.jog.2014.07.003.

Blondel, P. (2012). Bathymetry and its applications, InTech, 148 pp.; ISBN 978-953-307-959-2.

Bosman, A., F.L. Chiocci and C. Romagnoli (2009). Morpho-structural setting of Stromboli volcano, revealed by high-resolution bathymetry and backscatter data of its submarine portions, Bulletin of Volcanology, 71, 1007-1019.

Bosman, A., D. Casalbore, C. Romagnoli and F.L. Chiocci (2014). Formation of an 'a' lava delta: insights from time-lapse multibeam bathymetry and direct observations during the Stromboli 2007 eruption, Bulletin of Volcanology, 76 (7), 1-12.

Bourillet, J.F., C. Edy, F. Rambert, C. Satra and B. Loubrieu (1996). Swath mapping system processing: Bathymetry and cartography, Marine Geophysical Researches, 18 (2-4), 487-506.

Calanchi, N., F. Lucchi, P.A. Pirazzoli, C. Romagnoli, C.A. Tranne, U. Radtke, J.L. Reyss and P.L. Rossi (2002). Late quaternary relative sea level changes and vertical movements at Lipari (Aeolian Islands), Journal of Quaternary Science, 17 (5-6), 459-467.

CARIS (2000). CARIS-HIPS (Hydrographic Information Processing System) and SIPS Professional v. 5.2 Software User Guide: MA-HIPS-UG-02-02; on line http: / / www.caris.com/.

Casalbore, D., A. Bosman and F.L. Chiocci (2012). Study of recent small-scale landslides in geologically active marine areas through repeated multibeam surveys: examples from the southern Italy, In: Submarine Mass Movements and Their Consequences, Springer Netherlands, 573-582.

Casalbore, D., A. Bosman, C. Romagnoli and F.L. Chiocci (2014a). Submarine mass-movements on volcanic islands: Examples from the Aeolian Archipelago (Italy), Engineering Geology for Society and Territory, vol. 4, Lollino et al. (eds.), 199-203.

Casalbore, D., A. Bosman, C. Romagnoli and F.L. Chiocci (2014b). Large-scale seafloor waveforms on the flanks of insular volcanoes (Aeolian Archipelago, Italy), with inferences about their origin, Marine Ge- ology, 355, 318-329.

Casalbore, D., A. Bosman, C. Romagnoli, M. Di Filippo and F.L. Chiocci (2014c). Morphology of Lipari offshore (southern Tyrrhenian Sea), Journal of Maps, 1-10.

Casalbore, D., A. Bosman, D. Ridente and F.L. Chiocci (2014d). Coastal and submarine landslides in the tectonically-active Tyrrhenian Calabrian Margin (southern Italy): examples and geohazard implications, In: Submarine Mass Movements and their Consequences, Springer International Publishing, 261-269.

Chiocci, F.L., and C. Romagnoli (2004): Terrazzi deposizionali sommersi nelle Isole Eolie (Sicilia), In: F.L. Chiocci, S. D’Angelo and C. Romagnoli (eds.), Atlas of Submerged Depositional Terraces along the Italian Coasts, Memorie Descrittive della Carta Geologica d'Italia, Istituto Poligrafico dello Stato (Roma), APAT, 58, 81-114.

Chiocci, F.L., C. Romagnoli, P. Tommasi and A. Bosman (2008). The Stromboli 2002 tsunamigenic submarine slide: characteristics and possible failure mechanisms, Journal of Geophysical Research: Solid Earth (1978-2012), 113, B10102; doi:10.1029/2007JB005172.

Colantoni, P., M. Gennesseaux, J.R. Vanney, A. Ulzega, G. Melegari and A. Trombetta (1992). Processi dinamici del canyon sottomarino di Gioia Tauro (Mare Tirreno), Giornale di Geologia, 3, 54/2, 199-213.

Esposito, A., G. Giordano and M. Anzidei (2006). The 2002-2003 submarine gas eruption at Panarea Island (Aeolian archipelago, Italy): structure and volcanology of the seafloor and implications for hazard evaluation, Marine Geology, 227, 119-134.

Fabris, M., P. Baldi, M. Anzidei, A. Pesci, G. Bortoluzzi and S. Aliani (2010). High resolution topographic model of Panarea Island by fusion of photogrammetric, lidar and bathymetric digital terrain models, The Photogrammetric Record, 25, 132, 382-401.

Forni, F., F. Lucchi, A. Peccerillo, C.A. Tranne, P.L. Rossi and M.L. Frezzotti (2013). Stratigraphy and geological evolution of the Lipari volcanic complex (central Aeolian archipelago), Geological Society, London, Memoirs 2013, 37, 213-279; doi:10.1144/M37.10.

International Hydrographic Organization (2005). Manual on hydrography, Publication C-13, 1st edition, May 2005, International Hydrographic Bureau, Munich.

Lambeck, K., F. Antonioli, A. Purcell and S. Silenzi (2004a). Sea-level change along the Italian coast for the past 10,000 yrs., Quaternary Science Reviews, 23, 1567-1598.

Lambeck, K., M. Anzidei, F. Antonioli, A. Benini and A. Esposito (2004b). Sea level in Roman times in the central Mediterranean and implications for recent 
change, Earth and Planetary Science Letters, 224, 563-575.

Lambeck, K., and A. Purcell (2005). Sea-level change in the Mediterranean since the LGM: Model predictions for tectonically stable areas, Quaternary Science Reviews, 24, 1969-1988.

Locat, J., and H.J. Lee (2002). Submarine landslides: advances and challenges, Canadian Geotechnical Journal, 39, 193-212.

Maramai, A., L. Graziani and S. Tinti (2005). Tsunamis in the Aeolian Islands (southern Italy): a review, Marine Geology, 215, 11-21.

Mastronuzzi, G., H. Brückner, P.M. De Martini and H. Regnauld (2013). Tsunami: from the open sea to the coastal zone and beyond, In: S. Mambretti (ed.), Tsunami: Primary Causes to Mitigation, WIT Press, Southampton, 168, 1-36.

Mattia, M., M. Palano, V. Bruno, F. Cannavò, A. Bonaccorso and S. Gresta (2008). Tectonic features of the Lipari-Vulcano complex (Aeolian archipelago, Italy) from 10 years (1996-2006) of GPS data, Terra Nova, 20 (5), 370-377.

Mazza, A. (2013). Scavo subacqueo in località Sottomonastero, Lipari (ME). Prima campagna 8-15 settembre 2013, Relazione preliminare della campagna di scavo 2013, Soprintendenza del Mare della Sicilia e Università degli Studi di Sassari (http:/ / www.re gione.sicilia.it/beniculturali/archeologiasottoma rina/).

Monecke, T., S. Petersen, M.D. Hannington, M. Anzidei, A. Esposito, G. Giordano, D. Garbe-Schönberg, N. Augustin, B. Melchert and M. Hocking (2012). Explosion craters associated with shallow submarine gas venting off Panarea Island, Italy, Bulletin of Volcanology, 74 (9), 1937-1944.

Morgan, L.A., W.C. Shanks III, D.A. Lovalvo, S.Y. Johnson, W.J. Stephenson, K.L. Pierce, S.S. Harlan, C.A. Finn, G. Lee, M. Webring, B. Schulze, J. Duhn, R. Sweeney and L. Balistrieri (2003). Exploration and discovery in Yellowstone Lake: results from high-resolution sonar imaging, seismic reflection profiling, and submersible studies, Journal of Volcanology and Geothermal Research, 122, 221-242.

Morhange, C., J. Laborel and A. Hesnard (2001). Changes of relative sea level during the past 5000 years in the ancient harbour of Marseilles, southern France, Palaeogeography, Palaeoclimatology, Palaeooecology, 166, 319-329.

Pesci, A., M. Fabris, D. Conforti, F. Loddo, P. Baldi and M. Anzidei (2007). Integration of ground-based laser scanner and aerial digital photogrammetry for topographic modelling of Vesuvio volcano, Journal of Volcanology and Geothermal Research, 162 (3), 123-138.
Pirazzoli, P.A., J. Laborel and S.C. Stiros (1996). Coastal indicators of rapid uplift and subsidence: examples from Crete and other eastern Mediterranean sitesm, Zeitschrift für Geomorphologie, N.F. Suppl.-Bd., 102, 21-35.

Romagnoli, C., D. Casalbore and F.L. Chiocci (2012). La Fossa Caldera breaching and submarine erosion (Vulcano Island, Italy), Marine Geology, 303-306, 87-98.

Romagnoli, C., D. Casalbore, A. Bosman, R. Braga and F.L. Chiocci (2013a). Submarine structure of Vulcano volcano (Aeolian Islands) revealed by high-resolution bathymetry and seismo-acoustic data, Marine Geology, 338, 30-45.

Romagnoli, C., D. Casalbore, G. Bortoluzzi, A. Bosman, F.L. Chiocci, F. D’Oriano, F. Gamberi, M. Ligi and M. Marani (2013b). Bathy-morphological setting of the Aeolian Islands, Geological Society, London, Memoirs, 37, 27-36; doi:10.1144/M37.4

Serpelloni, E., R. Bürgmann, M. Anzidei, P. Baldi, B. Mastrolembo Ventura and E. Boschi (2011). Strain accumulation across the Messina Straits and kinematics of Sicily and Calabria from GPS data and dislocation modeling, Earth and Planetary Science Letters, 298, 347-360; doi:10.1016/j.epsl.2010.08.005.

Tallarico, A., M. Dragoni, M. Anzidei and A. Esposito (2003). Modeling long-term ground deformation due to the cooling of a magma chamber: case of Basiluzzo Island, Aeolian Islands, Italy, Journal of Geophysical Research, 108 (B12), 2568; doi:10.1029/2002 JB002376.

Vecchio, A., M. Anzidei and V. Carbone (2014). New insights on the tsunami recording of the May 21, 2003, Mw 6.9 Boumerdès earthquake from tidal data analysis, Journal of Geodynamics, 79, 39-49.

Ventura, G. (2013). Kinematics of the Aeolian volcanism (southern Tyrrhenian Sea) from geophysical and geological data, In: F. Lucchi, A. Peccerillo, J. Keller, C.A. Tranne and P.L. Rossi (eds.), The Aeolian Islands Volcanoes, Geological Society, London, Memoirs, 37, 3-11.

Ware, C., W. Knight and D. Wells (1991). Memory intensive statistical algorithms for multibeam bathymetric data, Computers \& Geosciences, 17 (7), 985-993.

Weiss, R. (2008). Sediment grains moved by passing tsunami waves: Tsunami deposits in deep water, Marine Geology, 250, 251-257.

Corresponding author: Marco Anzidei,

Istituto Nazionale di Geofisica e Vulcanologia, Rome, Italy; email: marco.anzidei@ingv.it.

C 2015 by the Istituto Nazionale di Geofisica e Vulcanologia. All rights reserved. 